\title{
Tipología de productores de ganado bovino en la región indígena XIV Tulijá-Tseltal-Chol de Chiapas, México
}

\section{Typology of cattle producers in the indigenous region XIV Tulijá-Tseltal-Cho'l of the state of Chiapas, México}

\author{
J orge Antonio Velázquez Avendañoa
}

\begin{abstract}
RESUMEN
Con el objetivo de evaluar la tipología de productores en la región socio-económica XIV Tulijá-Tseltal-Chol en el estado de Chiapas, México se hizo un estudio con carácter regional de los sistemas productivos. Se utilizaron entrevistas directas con productores (317) de las unidades de producción agropecuaria, haciendo recorridos por los municipios de esta región que se caracterizan por estar formadas de etnias de origen mayense (Tseltales, Choles y Tsotsiles), con una fuerte presencia de mestizos y de descendientes de europeos. Se exploraron 48 variables que fueron preseleccionadas quedando 11 para su análisis por medio del análisis multivariado. Los resultados muestran que se pueden diferenciar cuatro tipos de productores que comparten actividades productivas, como dar sales minerales y participar en campañas zoosanitarias, pero, diferentes en otros aspectos como el nivel educativo. Otro aspecto compartido es el bajo nivel de desarrollo tecnológico que parece demostrar la escasa promoción de su uso que podría mejorar la capacidad productiva y que en apariencia parece estar limitado por la cantidad de terreno. Se concluye que la tipología descrita es factible de utilizarse como clasificación para comprender e impulsar que los recursos que se destinen para apuntalar la producción regional deben contener políticas diferenciadas, y a su vez generar tecnología moderna apropiada, de real aplicación a las condiciones geo-ecológicas de la región, así como la promoción del uso de la misma que reconozca la biodiversidad y la producción sustentable como parte de las estrategias de desarrollo.
\end{abstract}

PALABRAS CLAVE: Tipología. Sistemas productivos, Análisis multivariado.

\begin{abstract}
In order to assess the type of producer underlying the socio-economic region XIV Tulijá-Tseltal-Chól in the state of Chiapas, Mexico, a study was made on a regional basis of production systems. Direct interviews with producers (317) of agricultural production units by wandering around the towns of this region are characterized by being formed of ethnic groups of Mayan origin (Tzeltal, Chol and Tsotsiles), with a strong presence of mestizos and European descent. Forty eight (48) variables that were preselected leaving 11 for analysis by multivariate analysis were explored. The results show four types of producers who share productive activities like supplying minerals and animal health campaigns, but different in other aspects such as education. Another shared aspect is the low level of technological development that seems to show the poor promotion of its use that could improve the productive capacity that apparently seems to be limited by the amount of land. It is concluded that the type described is feasible to be used as qualifiers and push forward the resources devoted to underpin regional production must contain differentiated policies and in turn generate appropriate modern technology, real application to geo-ecological conditions region and promoting the use of it to recognize biodiversity and sustainable production as part of development strategies.
\end{abstract}

KEY WORDS: Typification. Productive system. Multivariate system.

Recibido el 22 de enero de 2014. Aceptado el 3 de marzo de 2015.

a Unidad Académica Multidisciplinaria de Yajalón, Universidad Intercultural de Chiapas. Corral de Piedra número 2, Tel: 9611310295 , San Cristóbal de Las Casas, 29299, Chiapas, México. jorgevelazqueza@yahoo.com.mx. 


\section{INTRODUCCIÓN}

La región socio-económica XIV denominada Tulijá-Tseltal-Chol al norte del estado de Chiapas, se le identifica como una de las regiones con mayor diversidad biocultural del sureste mexicano, ya que en ella confluyen las etnias Tseltal, Cho'l y en menor medida la Tsotsil, conjuntadas con una cultura mestiza y de descendientes europeos, principalmente alemanes, que llegaron a fines del siglo XIX(1), que contribuyeron a la conformación de los sistemas productivos vigentes en la región. En otras palabras, los ecosistemas regionales sostienen una diversidad de sistemas productivos, cuyas bases se asientan en la mega diversidad y heterogeneidad biológica cultural $(2,3)$, por lo consiguiente, sustentan las múltiples formas de organización técnica y económica de la producción. Los elementos que las conforman guardan cualidades y rasgos irrepetibles, producto de la diversidad biocultural de sus componentes que interactúan y se influyen mutuamente, originando un vasto entorno productivo cuyas raíces, posiblemente, se nutren en buena medida de conceptos propios de los sistemas Mesoamericanos $(4,5)$. No obstante, también comparten rasgos y propiedades que las hacen semejantes en algunos aspectos, y sus semejanzas permiten agruparlas para diversos propósitos, es decir, determinan una tipología de productores; aunque se debe reconocer que en esta región XIV poco se sabe de las características de los tipos de productores que funcionan ligados a estos sistemas, por lo que es indispensable como se menciona(6), conocer a detalle la realidad productiva e identificar los patrones productivos y factores limitantes en la que se encuentran.

Una de las premisas centrales del presente trabajo es la identificación de los diferentes tipos de productores ganaderos regionales a partir del análisis de indicadores socioeconómicofinancieros, y su evaluación sistemática en el marco de una visión de búsqueda y concepción de soluciones apropiadas a las condiciones de cada una de las categorías de productores,

\section{INTRODUCTION}

The socio-economic region XIV called TulijáTzeltanTseltal-Chol Cho'I north of Chiapas, in southern Mexico, is identified as one of the regions with the highest bio-cultural diversity of the Mexican southeast. This area brings together three ethnic groups TzeltanTseltal-Chol Cho'I and to a lesser extent TzotzilTsotsil that are conjoined with a mixture of mainly German culture of European descent that arrived in the late nineteenth century(1), where they contributed to the formation of existing cattle production systems in the region. Moreover, the regional ecosystems can support a diversity of production systems, its foundations are centered in the mega diversity and biological heterogeneity - culture $(2,3)$, supporting multiple forms of technical and economic organization of production. The elements that make them up consist of unique qualities and features, product of the biocultural diversity of its components that interact and influence each other, originating a vast productive environment whose roots are possibly derived largely from concepts of the original Mesoamerican system itself $(4,5)$. However, in some respects they also share characteristics and properties that make them similar, their similarities allowing for grouping for different purposes, i.e. for determining the typology of producers. Although it must be recognized that in this region XIV little is known about the characteristics of the types of producers that work in these systems, thus it is essential as mentioned(6) to know in detail the production situation by identifying patterns of production and their limiting factors.

One of the central premises of this study is to identify the different types of regional livestock producers from the analysis of socio-economic and financial indicators. This is accomplished by carrying out a systematic evaluation within a vision framework whereby solutions are found and designed that are appropriate for the conditions of each of the categories of producers, particularly small-scale farming systems, where economic access to financial 
particularmente en sistemas campesinos en pequeña escala, en los cuales el acceso a recursos económico-financieros para la puesta en marcha de proyectos viables representan los mayores costos(7). El objetivo de esta investigación fue analizar las diferentes características socioeconómicas de los sistemas productivos de la región XIV Tulijá-Tseltal-Chol del estado de Chiapas a fin de determinar los diferentes tipos de productores de ganado bovino.

\section{MATERIALES Y MÉTODOS}

La clasificación de la tipología de productores involucrados en los sistemas de producción bovina en esta región, se conforma a partir del reconocimiento de la biodiversidad de los múltiples componentes que la integran, en una dinámica de constante interacción de tiempo y espacio(8), por lo tanto, tomando en consideración que de esta variedad e interacción de sus componentes surgen conjuntos que conforman sistemas con funciones que le son propias, el concepto del sistema es multivariado(9), lo cual faculta a la aplicación de un modelo de estudio de las diversas variables exploradas que facilite observar las estructuras y funciones de los conjuntos o agrupamientos que de ella deriven, de tal forma que los datos obtenidos se puedan manejar por medio de diversas técnicas tales como el Análisis estadístico multivariado (AEM)(10,11).

El análisis de las diferentes variables para la definición de las tipologías de productores se inició a partir de noviembre de 2012 a mayo de 2013 en que se realizaron recorridos en diferentes predios rurales de los municipios de Salto de Agua, Tila, Tumbalá, Sabanilla, Yajalón, Chilón y Sitalá, Chiapas ubicados entre los $16^{\circ}$ $04^{\prime}$ y $17^{\circ} 56^{\prime} \mathrm{N}$, y $90^{\circ} 22^{\prime}$ y $92^{\circ} 42^{\prime} \mathrm{O}$, a 19 a 1,413 msnm(12), con el propósito de aplicar diversas encuestas y recabar información socioeconómico-financiera a los productores ganaderos.

Esta región se caracteriza por estar constituida por etnias de origen mayense, hacia el poniente resources for the implementation of viable projects present high costs(7). The objective of this research was to analyze the different socioeconomic characteristics of production systems in the region XIV Tulijá- TzeltanTseltal-Chol Cho'I of Chiapas to determine the different types of cattle producers.

\section{MATERIALS AND METHODS}

The classification of types of farmers involved in cattle production systems in this region is shaped by recognizing the biodiversity of multiple components integrated in a dynamic of constant interaction in terms of time and space(8). Therefore, considering that this variety and interaction of its components form systems with their own functions and arrangements, then the system can be best conceptualized in term of multivariate sets(9). Thus, the application of a model to study and explore the several variables to facilitate observed structures and functions of the sets or groups derived therefrom, require that the data be managed through various techniques such as multivariate statistical analysis $(M S A)(10,11)$.

The analysis of the different variables to define the types of producers was carried out from November 2012 to May 2013. Tours were conducted in different rural lands in the municipalities of Salto de Agua, Tila, Tumbalá, Sabanilla, Yajalón , Chilón and Sitalá, Chiapas located between $16^{\circ} 04^{\prime}$ and $17^{\circ} 56^{\prime} \mathrm{N}$, and $90^{\circ} 22^{\prime}$ and $92^{\circ} 42^{\prime} \mathrm{W}$, at 19 to $1,413 \mathrm{~m}$ asl(12). This was done in order to implement various surveys and collect socioeconomic and financial information from livestock producers.

This region is characterized as being comprised by people of Mayan ethnic origin, to the west dominated by TzeltanTseltal-Chol Cho'I in the southeast part and towards the northeast by Tzotzil Tsotsil people, with a strong presence of mestizo and European descendants particularly in Chilón, Yajalón, Tila and Salto de Agua(12). It has $4,673 \mathrm{~km}^{2}$ and has several types of 
dominado por los Tseltales, al suroriente por los Choles y una parte hacia el nororiente por Tsotsiles, con una fuerte presencia de mestizos y de descendientes de europeos particularmente en Chilón, Yajalón, Tila y Salto de Agua(12). Cuenta con $4,673 \mathrm{~km}^{2}$ y presenta varios tipos de clima: en las partes bajas de Salto de agua es cálido húmedo con lluvias todo el año, y en las partes más altas de Tumbalá es templado subhúmedo, con lluvias en verano(13). Las principales actividades económicas en la región son agrícola, ganadera, forestal y turística.

Se aplicaron 317 entrevistas a productores ganaderos seleccionados de manera aleatoria, considerando como marco muestral a 6,508 productores de bovinos registrados en el censo ganadero de la región(14). Se utilizó un muestreo aleatorio simple y se consideró a cada unidad de producción (UP) como una unidad experimental representada por cada productor. La fórmula de muestreo utilizada fue(15):

$\mathrm{n}=\frac{\mathrm{N}}{\mathrm{Nd}^{2}+1}$

Donde: $\mathrm{N}=$ tamaño de población; $\mathrm{d}=$ precisión $(5 \%) ; n=$ tamaño de la muestra.

Se estudiaron 43 variables cuyos datos fueron organizados, sistematizados y analizados por medio de diversas técnicas multivariadas. El estudio minucioso de las variables originales derivó en una selección de 11 de aquéllas consideradas más importantes económica y productivamente por su contribución a un mejor análisis de los componentes tecnológicos y sociales utilizados en las UP. Las seleccionadas se sometieron primeramente a análisis factorial o de reducción de dimensiones(16), para que se resumiera y explicara la información contenida en el conjunto de variables observadas; identificando según sea el caso, otro número menor de variables no observadas, denominadas factores. Las primeras pruebas estadísticas coadyuvaron a confirmar las 11 variables originales que fueron sometidas al análisis de componentes principales (ACP), y posteriormente climate: in the lower parts where the water drains the climate is warm humid with rains all year, and in the highest parts of Tumbalá the climate is subhumid, with rains in the summer(13). The main economic activities in the region are agriculture, livestock, forestry and tourism.

Interviews with 317 livestock producers selected randomly were applied; the total sample size available was that of 6,508 bovine animal producers based on census data of cattle population in the region(14). A simple random sampling was used and each production unit (PU) was considered as an experimental unit and was represented by each producer. Sampling formula used was(15):

$\mathrm{n}=\frac{\mathrm{N}}{\mathrm{Nd}^{2}+1}$

Where: $N=$ population size; $d=$ precision $(5 \%)$; $\mathrm{n}=$ sample size.

A total of 43 variables were studied and the data was organized, systematized and analyzed using various multivariate techniques. The detailed study of the original variables resulted in a selection of 11 variables that were considered most important economically and productively for their contribution to a better analysis of the technological and social components used in the PU. The selected were subjected to a factorial analysis or a dimensional reduction(16), to be summarized and explained with information that contained the full set of observed variables; identifying as appropriate, a smaller number of unobserved variables, called factors. The first statistical tests helped to confirm the 11 original variables that were analyzed by principal component analysis (PCA), and then later by cluster analysis, this permitted identifying the different types of producers(17). The variables studied were, age and level of education of producers, total hectares and cattle area, animal heads and units, income (other income such as complementary professional activities, like employment, etc. were not 
al análisis de conglomerados, que permitió identificar los diferentes tipos de productores(17). Las variables estudiadas fueron, edad y grado de estudios de los productores, hectáreas totales y superficie ganadera, cabezas y unidades animales, ingresos (no se contemplaron otro tipo de ingresos complementarios como las actividades profesionales, empleo, etc., sino sólo aquéllos que derivan de la actividad pecuaria), participación en campañas zoosanitarias, equipamiento, infraestructura y aplicación de sales minerales.

Para realizar el análisis de las variables se aplicó la correlación de Pearson y después se procedió con estadística descriptiva a fin de estandarizar las variables, la prueba KMO y de Bartlett fueron especialmente útiles para definir el grado de estandarización(18). Posteriormente se utilizó el método de ACP para obtener las comunalidades y la prueba de varianza total que permitió reconocer el número de componentes mínimos que pudieran confirmar la contribución de las variables a explicar las diferentes tipologías. Se hizo la matriz de componentes así como la prueba de rotación con el método de Normalización Varimax. Posteriormente se hizo el análisis de conglomerados con la vinculación considered, but only those deriving from livestock rearing), participation in animal health campaigns, equipment, infrastructure and application of mineral salts.

For the analysis of the variables, Pearson's correlation was applied and then descriptive statistics were used to standardize the variables, $\mathrm{KMO}$ and Bartlett test were especially useful to define the degree of standardization(18). Later PCA method was used to obtain the commonalities and test the total variance that recognized the minimum number of components that could confirm the contribution of variables in order to explain the different types. Matrix components as well as the rotation method by using Varimax with Kaiser Normalization. Later cluster analysis with Ward was done, in order to lastly carry out frequency testing. The first allowed for the reduction of information and identified the variables that explain the system, the second revealed data concentrations for efficient clustering and classified production systems by identifying the major differences between types of producers. Analyses were performed using the PSPP program version 19(19).

Cuadro 1. Análisis estadísticos descriptivos de las variables estudiadas para el análisis de componentes de los tipos de productores de la región XIV Tulijá-Tseltal-Chol

Table 1. Descriptive statistical analysis of the variables studied for the analysis of components of types of producers in region XIV Tulijá-Tzeltan-Cho'l

\begin{tabular}{lccccrrr}
\hline & $\mathrm{N}$ & Minimum & Maximum & Sum & Mean & SD & Variance \\
\hline Age & 317 & 0 & 88 & 15,099 & 47.63 & 14.378 & 206.74 \\
Educational level & 317 & 0 & 9 & 1,066 & 3.36 & 2.074 & 4.30 \\
Total area, ha & 317 & 0 & 280.0 & $6,323.9$ & 19.94 & 25.536 & 652.11 \\
Cattle area, ha & 317 & 0 & 110.0 & $3,915.7$ & 12.35 & 13.206 & 174.39 \\
Cattle, AU & 317 & 0 & 224.0 & $6,952.7$ & 21.93 & 23.212 & 538.82 \\
Cattle, heads & 317 & 2 & 285 & 8,502 & 26.82 & 30.421 & 925.45 \\
Technology & 317 & 0 & 1 & 17 & 0.05 & 0.226 & 0.051 \\
Corrals & 317 & 0 & 1 & 295 & 0.93 & 0.255 & 0.065 \\
Fulfillment of NOM & 317 & 0 & 1 & 197 & 0.62 & 0.486 & 0.236 \\
Mineral salt & 317 & 1 & 3 & 626 & 1.97 & 0.791 & 0.626 \\
Gross income, \$ & 317 & 0 & 411,200 & $13 ‘ 609,051$ & 42,930 & 54,246 & $2.94 \mathrm{E}+09$ \\
\hline
\end{tabular}

$\mathrm{NOM}=$ Mexican oficial standards. 
de Ward, para finalmente realizar las pruebas de frecuencia. El primero permitió la reducción de la información e identificó las variables que más explicaron el sistema, el segundo reveló las concentraciones en los datos para un agrupamiento eficiente y clasificó los sistemas de producción identificando las principales diferencias entre tipos de productores. Los análisis se realizaron en el programa PSPP versión 19(19).

\section{RESULTADOS}

El análisis de las variables estudiadas mostró que las variables seleccionadas se encuentran estrechamente correlacionadas (Cuadro 1), mientras que la medida de adecuación muestral KMO fue de 0.822 que indica que el análisis factorial es adecuado, dado que el valor resultante entre más elevado mayor adecuación muestral. La prueba de esfericidad de Bartlett y de Ji cuadrada aproximada resultó altamente significativa $(P=0.001)$, que confirma la correlación entre las variables y por consiguiente la aplicabilidad del análisis factorial. El procedimiento de reducción de factores permitió visualizar el comportamiento de las variables y determinó cuatro factores en los que se pueden agrupar. En el Cuadro 2 se muestran las comunalidades, las cuales exponen la proporción de varianza explicada por los factores comunes en una variable, mientras que en el Cuadro 3 se muestran las varianzas para cada variable, que explican el $70 \%$ de la variabilidad de las variables originales.

Los resultados del análisis de las variables y su agrupamiento se pueden observar en el Cuadro 4 y Figura 1. Se conformaron cuatro grupos o tipologías con las siguientes características:

\section{Tipología I}

Este grupo se caracteriza por contar con una media de superficie total de 8.4 ha de las cuales 5.5 ha son para las actividades de ganadería, y para ello cuentan con 13.6 unidades animal, que representan una media de 16 cabezas de

\section{RESULTS}

The analysis of the variables showed that the selected variables are closely correlated (Table 1 ), while the Kaiser-Meyer-Olkin (KMO) measure of sampling adequacy was 0.822 indicating that the factor analysis is appropriate because the resulting value match better with higher number of samples. The Bartlett test of sphericity and the approximate chi-square was highly significant $(P=0.001)$, which confirms the correlation between variables and therefore the applicability of factorial analysis. The reduction process factors allowed for visualization of the behavior of the variables and identified four factors that can be grouped. Table 2 shows the commonalities, which expose the proportion of variance explained by the common factors into one variable, while in Table 3 the variances for each variable that account for $70 \%$ of the variability of the original variables are shown.

The results of the analysis of the variables and their grouping can be seen in Table 4 and Figure 1. Four groups or types are formed with the following characteristics:

\section{Type I}

This group is characterized by having a mean total area of 8.4 ha of which 5.5 ha are for

Cuadro 2. Resultado de las comunalidades

Table 2. Results of commonalities

\begin{tabular}{lcc}
\hline & Initial & Extraction \\
\hline Age & 1.000 & 0.772 \\
Level of schooling & 1.000 & 0.746 \\
Total surface & 1.000 & 0.515 \\
Livestock surface & 1.000 & 0.815 \\
Cattle, AU & 1.000 & 0.824 \\
Cattle, heads & 1.000 & 0.835 \\
Technology & 1.000 & 0.803 \\
Corrals & 1.000 & 0.322 \\
Compliance of NOM & 1.000 & 0.525 \\
Mineral salt & 1.000 & 0.683 \\
Gross income & 1.000 & 0.757 \\
NOM=_Mexican_oficial_standards & \\
\hline
\end{tabular}


TIPOLOGÍA DE PRODUCTORES EN LA REGIÓN INDÍGENA TULIJÁ-TSELTAL-CHOL

Cuadro 3. Varianza total explicada de las variables analizadas

Table 3. Total explained variance of the variables analyzed

\begin{tabular}{|c|c|c|c|c|c|c|c|c|c|c|c|}
\hline \multirow[b]{2}{*}{ Component } & \multicolumn{4}{|c|}{ Initial baseline values } & \multicolumn{4}{|c|}{ ESL } & \multicolumn{3}{|c|}{ RSL } \\
\hline & Total & $\%$ & Variance & $\%$ Cumulative & Total & $\%$ & Variance & $\%$ Cumulative & Total & $\%$ variance & $\%$ Cumulative \\
\hline 1 & 4.00 & & 36.38 & 36.382 & 4.00 & & 36.382 & 36.382 & 3.70 & 33.668 & 33.668 \\
\hline 2 & 1.47 & & 13.38 & 49.762 & 1.47 & & 13.380 & 49.762 & 1.49 & 13.560 & 47.229 \\
\hline 3 & 1.11 & & 10.09 & 59.858 & 1.11 & & 10.097 & 59.858 & 1.36 & 12.376 & 59.605 \\
\hline 4 & 1.01 & & 9.21 & 69.071 & 1.01 & & 9.213 & 69.071 & 1.04 & 9.466 & 69.071 \\
\hline 5 & 0.95 & & 8.71 & 77.782 & & & & & & & \\
\hline 6 & 0.71 & & 6.51 & 84.295 & & & & & & & \\
\hline 7 & 0.64 & & 5.90 & 90.198 & & & & & & & \\
\hline 8 & 0.46 & & 4.24 & 94.443 & & & & & & & \\
\hline 9 & 0.27 & & 2.48 & 96.932 & & & & & & & \\
\hline 10 & 0.21 & & 1.98 & 98.920 & & & & & & & \\
\hline 11 & 0.11 & & 1.08 & 100.000 & & & & & & & \\
\hline
\end{tabular}

$E S L=$ Extraction sums of squared loading.

RSL= Rotation sums of squared loading.

bovinos. No cuentan con tecnología para la producción pecuaria como molinos o picadoras, ni con corrales de manejo, aunque sí cumplen con las normas oficiales mexicanas como la campaña nacional contra la tuberculosis, brucelosis, y rabia. La edad promedio es de 46 años y tienen un promedio de nivel de estudio bajo, ya que la media resultante para este aspecto es de primaria concluida (posición 3), aunque el rango va desde personas sin estudios (posición 1) a secundaria inconclusa (posición 4). El nivel de ingreso bruto por concepto de ganadería (entendido como el valor de las ventas pecuarias, lo cual no constituye realmente su ingreso líquido o disponible para la familia, porque es el valor de las ventas e incluye los costos de producción), es de $\$ 20,895$, con un ingreso por hectárea de $\$ 3,778$. En este grupo se conjuntan el $6.3 \%$ de los productores, bien pueden ser catalogados como productores de muy bajos ingresos, ya que el nivel de ingreso bruto, el número de cabezas involucradas en la producción, la extensión de terreno disponible para la producción pecuaria, aunado a la evidente ausencia de tecnología apropiada, debería ser suficiente para esta clasificación. livestock activities, which is equivalent to 13.6 animal units, with an average of 16 heads of cattle. They do not have technology for livestock production, such as mills or choppers or even corrals to manage, although they meet with Mexican official standards which includes national vaccination campaign against tuberculosis, brucellosis and rabies. The average age is $46 \mathrm{yr}$ old and have on average a low level of schooling, since the resulting average is a completed elementary education (position 3), although the range varies from uneducated (position 1) to unfinished secondary schooling (position 4). The level of gross income from livestock (understood as the value of livestock sales, which is not really its liquid or available to the family income, because it is the value of sales includes production costs) is $\$ 20,895$, with income per hectare of $\$ 3,778$. In this group, $6.3 \%$ of producers may be classified as very low income, and that the level of gross income combined with the number of animals involved in the production, the amount of land available for livestock and the apparent absence of appropriate technology is appropriate for this classification. 
Tipología II

La superficie total es de 14.9 ha para una disponibilidad de 9.3 ha para la ganadería. Cuentan con un media de 19 cabezas que son
Type II

The total area is 14.9 ha for an availability of 9.3 ha for livestock. They have an average of 19 heads that are equivalent to 16.2 animal

Cuadro 4. Resumen de las variables estudiadas y su aportación a la tipología observada en la región XIV Tulijá-TseltalChol en Chiapas, México

Table 4. Summary of variables and their contribution to the type observed in the region XIV Tulijá-Tzeltan-Cho'l in Chiapas, Mexico

\begin{tabular}{|c|c|c|c|c|c|}
\hline & & \multicolumn{4}{|c|}{ Typology of producers } \\
\hline & & 1 & 2 & 3 & 4 \\
\hline Age & $\begin{array}{l}\text { Mean } \\
\text { Count } \\
\% \text { Observed }\end{array}$ & $\begin{array}{c}46 \\
20 \\
6.3\end{array}$ & $\begin{array}{c}49 \\
243 \\
76.7\end{array}$ & $\begin{array}{l}42 \\
50 \\
15.8\end{array}$ & $\begin{array}{c}48 \\
4 \\
1.3\end{array}$ \\
\hline Study level & $\begin{array}{l}\text { Mean } \\
\text { Count } \\
\% \text { Observed }\end{array}$ & $\begin{array}{c}3 \\
20 \\
6.3\end{array}$ & $\begin{array}{c}3 \\
243 \\
76.7\end{array}$ & $\begin{array}{l}5 \\
50 \\
15.8\end{array}$ & $\begin{array}{l}5 \\
4 \\
1.3\end{array}$ \\
\hline Total surface & $\begin{array}{l}\text { Mean } \\
\text { Count } \\
\% \text { Observed }\end{array}$ & $\begin{array}{c}8.4 \\
20 \\
6.3\end{array}$ & $\begin{array}{c}14.9 \\
243 \\
76.7\end{array}$ & $\begin{array}{l}44.0 \\
50 \\
15.8\end{array}$ & $\begin{array}{c}83.6 \\
4 \\
1.3\end{array}$ \\
\hline Livestock surface & $\begin{array}{l}\text { Mean } \\
\text { Count } \\
\% \text { Observed }\end{array}$ & $\begin{array}{c}5.5 \\
20 \\
6.3\end{array}$ & $\begin{array}{c}9.3 \\
243 \\
76.7\end{array}$ & $\begin{array}{l}25.5 \\
50 \\
15.8\end{array}$ & $\begin{array}{c}68.0 \\
4 \\
1.3\end{array}$ \\
\hline Cattle, AU & $\begin{array}{l}\text { Mean } \\
\text { Count } \\
\% \text { Observed }\end{array}$ & $\begin{array}{c}13.6 \\
20 \\
6.3\end{array}$ & $\begin{array}{c}16.2 \\
243 \\
76.7\end{array}$ & $\begin{array}{l}43.8 \\
50 \\
15.8\end{array}$ & $\begin{array}{c}141.7 \\
4 \\
1.3\end{array}$ \\
\hline Cattle, heads & $\begin{array}{l}\text { Mean } \\
\text { Count } \\
\% \text { Observed }\end{array}$ & $\begin{array}{c}16 \\
20 \\
6.3\end{array}$ & $\begin{array}{c}19 \\
243 \\
76.7\end{array}$ & $\begin{array}{l}52 \\
50 \\
15.8\end{array}$ & $\begin{array}{r}217 \\
4 \\
1.3\end{array}$ \\
\hline Technology & $\begin{array}{l}\text { Mean } \\
\text { Count } \\
\% \text { Observed }\end{array}$ & $\begin{array}{c}0 \\
20 \\
6.3\end{array}$ & $\begin{array}{c}0 \\
243 \\
76.7\end{array}$ & $\begin{array}{l}0 \\
50 \\
15.8\end{array}$ & $\begin{array}{l}0 \\
4 \\
1.3\end{array}$ \\
\hline Corrals & $\begin{array}{l}\text { Mean } \\
\text { Count } \\
\% \text { Observed }\end{array}$ & $\begin{array}{c}0 \\
20 \\
6.3\end{array}$ & $\begin{array}{c}1 \\
243 \\
76.7\end{array}$ & $\begin{array}{l}1 \\
50 \\
15.8\end{array}$ & $\begin{array}{l}1 \\
4 \\
1.3\end{array}$ \\
\hline Compliance with NOM & $\begin{array}{l}\text { Mean } \\
\text { Count } \\
\% \text { Observed }\end{array}$ & $\begin{array}{c}1 \\
20 \\
6.3\end{array}$ & $\begin{array}{c}1 \\
243 \\
76.7\end{array}$ & $\begin{array}{l}1 \\
50 \\
15.8\end{array}$ & $\begin{array}{l}1 \\
4 \\
1.3\end{array}$ \\
\hline Mineral salt & $\begin{array}{l}\text { Mean } \\
\text { Count } \\
\% \text { Observed }\end{array}$ & $\begin{array}{c}2 \\
20 \\
6.3\end{array}$ & $\begin{array}{c}2 \\
243 \\
76.7\end{array}$ & $\begin{array}{c}2 \\
50 \\
15.8\end{array}$ & $\begin{array}{l}2 \\
4 \\
1.3\end{array}$ \\
\hline Gross income & $\begin{array}{l}\text { Mean } \\
\text { Count } \\
\% \text { Observed }\end{array}$ & $\begin{array}{c}20895.0 \\
20 \\
6.3\end{array}$ & $\begin{array}{c}30132.5 \\
243 \\
76.7\end{array}$ & $\begin{array}{c}91983.0 \\
50 \\
15.8\end{array}$ & $\begin{array}{r}317450.0 \\
4 \\
1.3\end{array}$ \\
\hline
\end{tabular}

$\mathrm{NOM}=$ Mexican oficial standards 
16.2 unidades animales, las cuales no cuentan con tecnología ni equipo moderno aunque sí con corrales de manejo. Cumplen con las normas zoosanitarias y proporcionan sales minerales. Los ingresos anuales por las actividades de ganadería en promedio se encuentran en $\$ 30,132$. Este agrupamiento cuenta con una media de edad de 49 años y una media sobre el nivel de estudio de primaria terminada (posición 3), aunque el rango indica que también participan aquéllos con nivel universitario (posición 7). Cabe resaltar que en este conjunto se encuentra el mayor número de unidades productivas participantes, con una media de $76.7 \%$ del total. Aunque guarda semejanza con el primer grupo, éste podría clasificarse como productores de bajos ingresos, considerando que el nivel de ingreso bruto aunado a la cantidad de cabezas de ganado y superficie ganadera es un poco mayor que el anterior; no obstante, cuando se aplica el ingreso por hectárea es el de menor ingreso $(\$ 3,242)$ de todos los grupos, a pesar de que en este agrupamiento ya se encuentra un mejor nivel tecnológico. Esta tipología resalta su importancia por la concentración de unidades que en ella se ubican, y que debería junto a la anterior sumar otro tipo de apoyos y estrategias para apuntalar su desarrollo.

\section{Tipología III}

Cuentan con una superficie ganadera de 25.5 ha para una superficie total de 44 ha. Una media de 52 cabezas o 43.8 unidades animal. Cuentan con corrales y participación en campañas zoosanitarias, además de que proporcionan sales minerales; no obstante, carecen de tecnología moderna. El ingreso bruto es de $\$ 91,983$ y participa de $15.8 \%$ del total de unidades productivas; aquí también se registra un ingreso por hectárea no diferente al de los otros grupos $(\$ 3,607)$. La edad de los productores es de 42 y cuenta con un nivel de estudio de secundaria terminada (posición 5). Estas características apuntan a un sector con mejores niveles de ingresos brutos, en el que el nivel de estudios es mayor, ya que el rango
Figura 1. Combinación de conglomerados de distancia rescalados de los sitios de estudio

Figure 1. Combination of distance clusters rescaled to the study sites

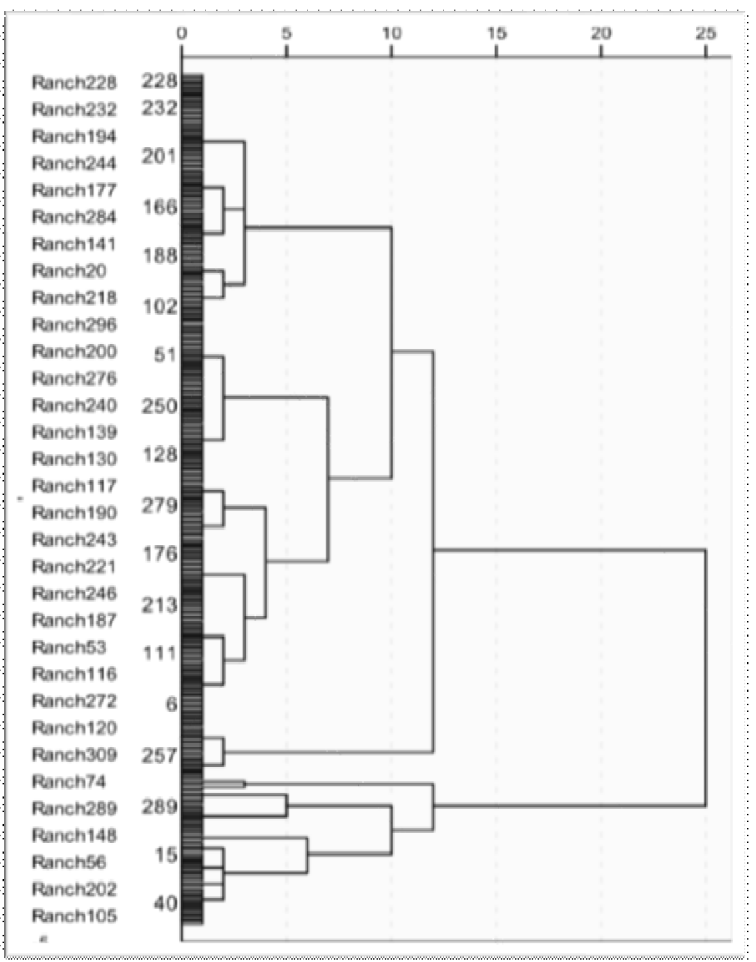

units, they have no modern technology or although they manage corrals. They comply with the animal health requirements and provide minerals. Annual revenues for livestock activities are on average $\$ 30,132$. This grouping has an average age of $49 \mathrm{yr}$ and an average level of study of a completed elementary education (position 3), although the range indicates that some have also attended university (position 7). Significantly, in this group there is the largest number of participants involved in productive units, with an average of $76.7 \%$ of the total. Although reminiscent of the first group these could be classified as low-income producers, considering that the level of gross income together with the amount of livestock and livestock area is a little higher than the previous. However, when income is applied per hectare, they have the lowest income $(\$ 3,242)$ of all 
considera hasta un nivel de preparatoria terminada (posición 6) incluso universitaria (posición 7). Se puede catalogar como un grupo en desarrollo, aunque es necesario que se apuntale con mejores promociones del uso tecnológico y mejoramiento de la infraestructura.

\section{Tipología IV}

Cuenta con una superficie total de 83.6 ha y destina 68 ha para las actividades de ganadería. Una media de 141.7 unidades animal que representan 217 cabezas de ganado bovino. Se puede observar que este agrupamiento tampoco utiliza equipo moderno para la producción, aunque sí cumplen con las normas oficiales zoosanitarias, así como la proporción de sales minerales. Este grupo es el de menor participación de unidades de producción pecuaria con $1.3 \%$ del total, aunque es el de mayor ingresos con \$317,450; sin embargo, llama la atención que el ingreso por hectárea es sólo ligeramente diferente a los demás grupos, ya que tiene un ingreso por $\$ 4,668.38$. Quienes aquí participan cuentan con un promedio de edad de 48 años y una media del nivel de estudios correspondiente a la secundaria terminada (posición 4); no obstante, el rango y la máxima indican que mantienen un nivel de estudios universitarios (nivel 7), el cual es superior a los dos primeros conjuntos; pero, igual al tercer agrupamiento. Este grupo cuenta con el mayor nivel de desarrollo de esta región considerando sus ingresos, educación y la capacidad productiva demostrada con las superficies y la cantidad de animales involucrados; no obstante, limitada por la cantidad de unidades productivas que en ella participan y por el pobre desarrollo tecnológico que tienen, que aunque el nivel de infraestructura ganadera es mejor que el resto, no es suficiente para el nivel de tipología que se exhibe.

\section{DISCUSIÓN}

El análisis de los resultados guardan semejanza con los encontrados por otros autores, quienes groups, although in this grouping there is a better technological level. This typology highlights its importance due to number of concentrated units located therein, and that they should, similar to the prior type, look for assistance and other strategies to help support their development.

\section{Type III}

They have a cattle area of 25.5 ha for a total area of 44 ha. An average of 52 heads or 43.8 animal units. They have corrals and they participate in animal health campaigns, besides providing mineral salts; however, they lack modem technology. The gross income is \$ 91,983 and they participate by having $15.8 \%$ of all production units. Here income per hectare is also recorded but it is not different from the other groups $(\$ 3,607)$. The age of farmers is $42 \mathrm{yr}$ and has a secondary level of schooling completed (position 5). These characteristics point to a sector with higher levels of gross income, where the educational level is higher, because the range considered an education level where high school was completed (position 6), or even university (position 7). It is a group that can be ranked as growing but is necessary to point out that they need better use of technological developments and improved infrastructure.

\section{Type IV}

Has a total area of 83.6 ha and 68 ha are intended for livestock activities. An average of 141.7 animal units representing 217 head of cattle. It can be seen that this grouping does not use modern equipment for production, although they comply with the official standards of animal health, including the right proportion of mineral salts. This group has the lowest share of livestock production units with $1.3 \%$ of the total, although they have a higher income $\$ 317,450$. However, it is noteworthy that the income per hectare is only slightly different from the other groups, as they have an income of $\$ 4,668$.38. Those involved here have an average age of $48 \mathrm{yr}$ and an average level of study 
también con variables semejantes a las aquí propuestas, lograron establecer un nivel aceptable de estandarización y de correlación de sus variables, clasificando cuatro tipos de productores $(7,20)$. Se observa semejanza en cuanto a la extensión utilizada para realizar las actividades pecuarias; pero, diferentes en los niveles de desarrollo tecnológico y disposición de cabezas por hectárea(7).

Esta situación puede deberse a que los productores de la región de estudio no han adoptado el uso consciente de la tecnología moderna, sustentable y apropiada a la región como estrategias que son útiles para apuntalar la producción.

Es importante resaltar que una variable que los análisis estadísticos del presente estudio no ponderaron es lo relacionado con los costos de producción; no fue seleccionada debido a que más del $70 \%$ de los entrevistados no brindaron información al respecto, debido probablemente a que no utilizan registros, por lo consiguiente, desconocen sus costos de producción, es decir cuánto le cuesta producir cada unidad de producto, y desconocen cuál es su ganancia o pérdida por cada unidad de producto. En consecuencia, su capacidad gerencial es extremadamente baja.

En suma, la región XIV Tulijá-Tseltal-Chol perfila cuatro tipos de productores claramente delimitados, que si bien comparten afinidades en algunas actividades productivas como la proporción de sales minerales y participación en campañas zoosanitarias, son diferentes en algunos otros como el del nivel educativo, que se puede observar como una diferencia de mucha importancia, si consideramos que el rango en el primer grupo toca incluso a personas sin estudio, mientras que en el cuarto grupo se encuentran personas con mayores estudios incluso de nivel universitario.

Otro aspecto importante que se comparte es el nivel de desarrollo tecnológico, que ningún grupo presenta, lo cual es alarmante, ya que corresponding to a completed secondary education (position 4). However, the maximum and range indicate that they have university level studies (level 7), which is higher than the first two groups, but like the third group. This group has the highest level of development in this region, considering their income, education and demonstrated productive capacity of the areas and the number of animals involved. However, they are limited by the amount of productive units that can participate and poor technological development, although the level of livestock infrastructure is better than the rest, it is not sufficient for the level of typology exhibited.

\section{DISCUSSION}

The analysis of the results are reminiscent of those found by other authors, where they also used similar variables to those proposed here and were able to establish an acceptable level of standardization and correlation of their variables, were they also classified four types of producers $(7,20)$. Similar results are observed for the area of extension used for livestock activities; but differences in levels of technological development and arrangement of heads per hectare were found(7).

This situation may be because the producers of the study region have not adopted the conscious use of modern sustainable technology strategies that are more appropriate to the region and that are useful in bolstering production.

It is important to point out that a variable that the statistical analysis in this study did not consider was production costs. It was not considered because over $70 \%$ of respondents did not provide information; it's probably because they do not keep or use records, so therefore they do not know their actual production costs, i.e. how much it costs to produce each unit of output, and thus do not know their profit or loss per unit of output. Consequently, their management capabilities are extremely low. 
parece demostrar una escasa valoración de la importancia de su uso, aunque también se debe considerar el poco ingreso bruto de la mayoría de la unidades de producción, que puede repercutir en la poca motivación para el no uso de tecnología moderna, en función de que la promoción y la aplicación de tecnología apropiada a las condiciones geo-ecológicas de la región podría mejorar la capacidad productiva e incrementar la cantidad de ganado destinado a la producción que en apariencia parece estar limitado por la cantidad de terreno; sin embargo, el uso de tecnología moderna, sustentable y apropiada podría contribuir a subsanar este aspecto, incluso en el tipo I que no cuenta ni siquiera con corrales para el manejo del ganado.

\section{CONCLUSIONES E IMPLICACIONES}

Por sus características, los cuatro tipos observados y descritos implican que es factible utilizar esta clasificación para comprender e impulsar que los recursos que se destinen para apuntalar la producción ganadera, deben contener políticas claramente diferenciadas y promover el uso de tecnología moderna apropiada, de real aplicación a las condiciones geo-ecológicas de la región, que reconozca la biodiversidad y la producción sustentable como parte de las estrategias de desarrollo.

\section{LITERATURA CITADA}

1. De Vos J. Oro verde, la Conquista de la selva lacandona por madereros tabasqueños, 1822-1949. 1a ed. México: Fondo de Cultura Económica; 1988.

2. Boege SE. Centros de origen, pueblos indígenas y diversificación del maíz. Ciencias 2008;(92-93):18-28.

3. Viqueira JP. La comunidad india en México en los estudios antropológicos e históricos. Viqueira JP, Ruz MH. editores. Chiapas: Los rumbos de otra historia. 3a ed. México: Centro de Estudios Superiores de México y Centroamérica; 1995.

4. Boege SE. Territorio y diversidad biológica, la agrobiodiversidad de los pueblos indígenas de México. En: Biodiversidad y conocimiento tradicional en la sociedad rural México: Centro de Estudios para el Desarrollo Rural Sustentable y Soberanía Alimentaria. 2006:237-298.

5. Carrillo TC. El origen del maíz. Naturaleza y cultura en Mesoamérica. Ciencias 2008; (92-93):4-14.
In sum, the region XIV Tulijá-Tzeltan-Cho'I have four profiles types of clearly defined producers, even if they share similarities in some productive activities as the proportion of minerals and participation in animal health campaigns, they are different in some others. Such as educational level that can be seen as a very important difference considering that the range in the first group includes even people without studies, while in the fourth group it includes individuals with higher studies even at the university level.

Another important aspect that is shared by all groups is the low level of technological development. This is alarming as it seems to demonstrate a lack of appreciation of the importance of their use, but one should also take into account the little gross income of most production units is probably impacting the lack of motivation for using modern technology. The application of appropriate technology to the geo-ecological conditions of the region could improve the productive capacity and increase the amount of cattle for production, which apparently seems to be limited by the amount of land. However, the use of modern, sustainable and appropriate technology could help remedy this aspect, even with type I that do not even have corrals for livestock management.

\section{CONCLUSIONS AND IMPLICATIONS}

Due to its characteristics, the four types observed and described imply that it is feasible to use this classification to understand and support the resources devoted to bolster livestock production. These must also have specific policies that promote the use of appropriate modern technology, with real applications suitable to the geo-ecological conditions of the region, while also recognizing biodiversity and sustainable production as part of its development strategies.

End of english version 
6. Vilaboa Al, Díaz RP, Ruiz RO, Platas RD, González MS, Juárez LF. Caracterización socioeconómica y tecnológica de los agro-ecosistemas con bovinos de doble propósito de la región de Papaloapan Veracruz, México. Trop Subtrop Agroecos 2009; 10(1):53-62.

7. Espinosa OA, Álvarez MA, Del Valle MC, Chauvette M. La economía de los sistemas campesinos de producción de leche en el Estado de México. Téc Pecu Méx 2005;43(1):3956.

8. Escobar G, Berdegué J. Metodología para la tipificación de sistemas de finca. Escobar G, Berdegué J editores. Tipificación de sistemas de producción agrícola. Chile: Red Internacional de Metodología e Investigación de Sistemas de Producción (RIMISP); 1990:13-44.

9. Valerio $C D$, Acero CR, Perea JM, García MA, Castaldo A, Peinado J. Metodología para la caracterización y tipificación de sistemas ganaderos. Anim Gestión 2004;(1):1-9.

10. Hart RD. Agroecosistemas: conceptos básicos. $1 \underline{a}$ ed. Turrialba, Costa Rica: Centro Agronómico Tropical de Investigación y Enseñanza; 1980.

11. Rodríguez QP. Sistemas de producción, conceptos y métodos de aplicación. En: Curso de especialización en interpretación de imágenes de sensores remotos aplicada a levantamientos rurales. Colombia: Instituto Geográfico Agustín Codazzi (IGAC); 1993;40-69.

12. CEIEG. Comité Estatal de Información Estatal de Información Estadística y Geografía. Caracterización de las Regiones de
Chiapas. México. 2013. http: // www ceieg chiapas gob mx / home / ? cat=207 y en: www.chiapas.gob.mx/gobiernosmunicipales/regiones.

13. Parra VMR. The agricultural sub development in the highlands of Chiapas. la ed. México: CIES-UACH Collection University Notebooks. 1989.

14. INEGI. Censo Agrícola, Ganadero y Forestal. México. 2007. http://www.inegi.org.mx/prod_serv/contenidos/espanol/ bvinegi/productos/censos/agropecuario/2007/panora_agrop/ chis/Panagrochis1.pdf.

15. Hernández SP, Fernández CC, Baptista LC. Metodología de la Investigación, 2a ed. México: Mc Graw Hill; 2001.

16. Morrison DE. Multivariate statistical methods. 2a ed. USA: McGraw Hill Book Company; 1976.

17. J honson DE. Métodos multivariados aplicados al análisis de datos. 2a ed. México: International Thomson Editores; 2000.

18. Ruiz M, Ruiz J, Torres V, Cach J. Estudio de sistemas de producción de carne bovina en un municipio del estado de Hidalgo, México. Rev Ciencia Agríc 2012;46(3):261265.

19. SPSS. User's Guide: Statistics (version 19). NY. USA: SPSS Inc. 2010.

20. Leos RJ, Serrano PA, Salas GJ, Ramírez MP, Sagarnaga VM. Caracterización de ganaderos y unidades de producción pecuaria beneficiarios del Programa de estímulos a la productividad ganadera (PROGAN) en México. Agric Soc Des 2008;5(2):213-230. 
